\title{
Digestibility Value and Fermentation Level of Local Feed-Based Ration for Sheep
}

\author{
Hamdi Mayulu ${ }^{1}$, Nur Risma Fauziah ${ }^{1}$, Muh Ichsan Haris ${ }^{1}$, Marry Christiyanto ${ }^{2}$, and Sunarso ${ }^{2}$ \\ ${ }^{1}$ Animal Sciences Departement of Agricultural Faculty, Mulawarman University, EastKalimantan \\ ${ }^{2}$ Diponegoro University, Semarang, Indonesia \\ Corresponding author email: mayoeloehsptno@yahoo.com
}

\begin{abstract}
Feed Digestibilityis an important indicator which can be used as a guideline to determine the amount of nutrient and feed that can be absorbed by digestive tract. The objective of the research was to determine the value dry matter digestibility (DMD), organicmatter digestibility (OMD), $\mathrm{NH}_{3}$ fermentation level and volatile fatty acid (VFA) fermentation level. The research was conducted on January 2018 in Animal Feed and Nutrition Laboratory of Animal Husbandry and Agriculture Faculty, Diponegoro University Semarang. The research method used was in vitro analysis with complete randomized design with five treatments and four replicates. The data were analyzed with analysis of variance at $95 \%$ significant level, followed by Duncan Multiple Range Test. The results showed that the highestscore of $D M D$ was $T_{5}=56.51 \pm 0.33 \%, T_{4}=56.41 \pm 2.11 ; T_{3}=55.86 \pm 0.83$; highestscoreof $\mathrm{OMD}$ was $\mathrm{T}_{5}=62.48 \pm 0.39 \%, \mathrm{~T}_{4}=61.87 \pm 1.60 ; \mathrm{T}_{3}=60.86 \pm 1.10$, the highest $\mathrm{NH}_{3}$ concentration was $\mathrm{T}_{3}=6.07 \pm 1.55 \mathrm{mM}$, andthe highestVFA concentration was $\mathrm{T}_{5}=55.25 \pm 3.40 \mathrm{mM}$. Sheep's localfeed-based ration was significantly $(\mathrm{P}<0.05)$ influenced in vitroDMD, OMD, $\mathrm{NH}_{3}$ fermentation level and VFAfermentation level.

Keywords: Local feed, ration, in vitro, digestibility, dry matter, organic matter.
\end{abstract}

Abstrak. Kecernaan pakan merupakan indikator yang penting sebagai petunjuk menentukan jumlah nutrien pakan yang mampu diserap oleh saluran pencernaan. Penelitian bertujuan untuk mengetahui nilai kecernaan bahan kering (KCBK), kecernaan bahan organik ( $\mathrm{KCBO})$, tingkat fermentasi $\mathrm{NH}_{3}$ dan tingkat fermentasi volatyle fatty acid (VFA). Penelitian dilaksanakan pada bulan Januari 2018 di Laboratorium Ilmu Nutrisi dan Makanan Ternak Fakultas Peternakan dan Pertanian Universitas Diponegoro Semarang.Metode Penelitian menggunakan analisis in vitro dengan rancangan acak lengkap (RAL) lima perlakuan, dan empat ulangan. Data dianalisis menggunakan analysis of variance pada taraf signifikansi 95\%, dilanjutkan uji Duncan Multple Range Test. Hasil penelitianmenunjukkan bahwa nilai KcBK terbaik berturut-turut $T_{5}=56,51 \pm 0,33 \%, T_{4}=56,41 \pm 2,11$; $\mathrm{T}_{3}=55,86 \pm 0,83$; nilai $\mathrm{KcBO}$ terbaik $\mathrm{T}_{5}=62,48 \pm 0,39 \%, \mathrm{~T}_{4}=61,87 \pm 1,60 ; \mathrm{T}_{3}=60,86 \pm 1,11$; konsentrasi $\mathrm{NH}_{3}$ terbaik $T_{3}=6,07 \pm 1,55 \mathrm{mM}$, dankonsentrasi VFA terbaik $T_{5}=55,25 \pm 3,40 \mathrm{mM}$. Ransum domba berbasis pakan lokal secara in vitro berpengaruh nyata $(\mathrm{P}<0,05)$ terhadap $\mathrm{KCBK}, \mathrm{KcBO}$, tingkat fermentasi $\mathrm{NH}_{3}$ dan tingkat fermentasi VFA. Kata Kunci: Pakan lokal, ransum, in vitro, kecernaan, bahan kering, bahan organik.

\section{Introduction}

Sheep is one of meat-producer commodity which is very potential to be promoted to become superior product in order to fulfill domestic or even export market (Mansjoer et al., 2007). Sheep livestock enterprise is special as it can give farmers a sustainable economy; however the average productivity hasn't yet optimum. This phenomenon is closely related due to insufficient feed supply, the genetic quality of the breeding and fault in the raising system (Khanum et al., 2007). Sheep population is very promising which can be seen from the population in 2016 achieved to number 16.462.274 heads. The increasing population may happen in East Kalimantan because of large field but currently the sheep population is still few only 287 heads in 2016 (Ministry of Agriculture, 2017).

Livestock productivity is influenced by genetic, feed and raising management (Wiyatna et al., 2012). A qualified feed is an important factor to fulfill livestock growth needs to achieve maximum beef production as well as to achieve a successful livestock enterprise (Yakin et al., 2012) so income of farmers increase. Ruminant is a livestock commodity that can utilize a low feedstuffs quality and high crude fiber and then digests into a qualified feeds (Lunagariya et al., 2017). feedstuffs used to formulate ration should contain adequate nutrient content (protein, 
carbohydrate, fat, mineral, vitamin and water) for sheep thus can produce optimum result. Ration fed into sheep should contain and formulated in a certain procedure.

Utilization of local feedstuffs material which doesn't compete with human needs is very potential to be researched and studied. A new resource of feedstuffs which doesn'tcompete with human food chain is needed to be explored. Utilization of local feedstuffs for sheep is an alternative to provide sustain feedstuffs a whole year with quantity and quality that meet sheep's needs standard. The character of sheep itself is very selective to their feeding supply so sheep needs better digestibility value compared with cattle (Adiwimarta, 2012). Supan-supan legume (Neptunia plena L. Benth) or what is known as Neptunia plena and Kolomento grass (Leersia hexandra Swartz) or what is known as Leersia hexandra are alternative feeds that can be given to sheep.

Forage as the main feed has not yet produced maximum production for sheep, thus a qualified local feedstuffs is very recommended to fulfill the nutrient needs of sheep. The nutrient composition of a ration can be determined based on the ration-chemical composition, while the nutrient utilization can be biologically determined from digestibility and fermentation level test by using in vitro method (Khanum et al., 2007). Therefore, the objective of this research was to determine the digestibility score and fermentation rate of sheep's local feedstuffsbased ration.

\section{Materials and Method}

The research was conducted on January 2018 at the Laboratory of Animal Feed and Nutrition, Faculty of Animal and Agricultural Sciences, Diponegoro University, Semarang. The materials used in the study were: a) ration consisting of Neptunia plena and Leersia hexandra, other feed ingredients (ricebran, corn, palm oil cake and calliandra); b) in vitro material using: sheep rumen fluid taken from Boestaman Semarang Slaughterhouse, Mc Dougall solution (artificial saliva), pepsin-HCL solution as protein degrading enzyme, ice water to stop the fermentation process, aquades, $\mathrm{CO}_{2}$, indicator of metyl red and bromycresol green, saturated sodium carbonate $\left(\mathrm{Na}_{2} \mathrm{CO}_{3}\right)$, boric acid solution, $0.5 \% \mathrm{HCl}$, phenolptalein $1 \%$ indicator, sulfuric acid $0.0055 \mathrm{~N}$, vaselin, sulfuric acid $\left(\mathrm{H}_{2} \mathrm{SO}_{4}\right) 15 \%$ and $0.5 \mathrm{~N} \mathrm{NaOH}$ and whatman filter paper 41 . The ration was prepared with crude protein content of $11-14 \%$ and $60 \%$ TDN content.

\section{Experimental Design}

The experimental design used in the research was complete randomized design (CRD) with 5 treatments, as shown in Table 1.

\section{In vitro Analysis}

In vitro analysis to determine dry matter digestibility (DMD), organic matter digestibility (OMD), $\mathrm{NH}_{3}$ fermentation rate, and volatyle fatty acid (VFA) fermentation rate was carried out using the method of Tilley and Terry (1963).

1. Equation for DMD:

DM Digestibility

$=\frac{\text { DM weight of sample }-(\text { DM residue }- \text { blanks })}{\text { DM weight of sample }} \times 100 \% \ldots . . . .(1)$

2. Equation for $\mathrm{OMD}$ :

OM Digestibility

$=\frac{\text { OM weight of sample }- \text { (OM residue }- \text { blanks })}{\text { OM weight of sample }} \times 100 \% \ldots$ (2)

DM sample = sample weight $x \%$ DM

DM residual = weight after oven-CP-filter paper

Blanks = weight after oven-CP-filter paper

OM sample= DM weight of sample $\mathrm{x} \% \mathrm{OM}$

$\% \mathrm{OM}=100 \% \mathrm{DM}$ - (\% Ash content in DM)

$\mathrm{OM}$ residue $=$ weight after oven - weight after tanur-filter paper

3. Equation for $\mathrm{NH}_{3}$ Amonia Production: $\mathrm{NH}_{3}$ Production $(\mathrm{mM})=\left(\mathrm{ml}\right.$ titranx $\left.\mathrm{N} \mathrm{H}_{2} \mathrm{SO}_{4} \times 1000\right)$...(3) $\mathrm{N}=$ Solution normality of $\mathrm{H}_{2} \mathrm{SO}_{4}$ 
Table 1. Ration Feedstuffs and Chemical Composition (\% DM)

\begin{tabular}{|c|c|c|c|c|c|}
\hline \multirow{2}{*}{ Composition } & \multicolumn{5}{|c|}{ Treatment } \\
\hline & $\mathrm{T}_{1}$ & $\mathrm{~T}_{2}$ & $\mathrm{~T}_{3}$ & $\mathrm{~T}_{4}$ & $\mathrm{~T}_{5}$ \\
\hline & \multicolumn{5}{|c|}{ 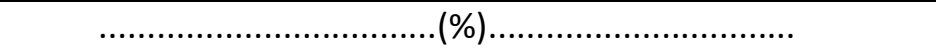 } \\
\hline \multicolumn{6}{|l|}{ Feedstuffs: } \\
\hline Leersia hexandra & 100.00 & - & 15.00 & 20.00 & 25.00 \\
\hline Neptunia plena & - & 100.00 & 15.00 & 20.00 & 25.00 \\
\hline Corn & - & - & 3.00 & 39.00 & 42.00 \\
\hline Rice bran & - & - & 14.00 & 9.50 & 1.00 \\
\hline Palm oil cake & - & - & 14.50 & 3.00 & 2.00 \\
\hline Calliandra & - & - & 7.50 & 8.50 & 5.00 \\
\hline Total & 100.00 & 100.00 & 100.00 & 100.00 & 100.00 \\
\hline \multicolumn{6}{|l|}{ Feed Nutrient: } \\
\hline DM & 85.09 & 86.89 & 89.92 & 89.65 & 88.69 \\
\hline OM & 90.43 & 95.18 & 94.30 & 94.27 & 94.42 \\
\hline $\mathrm{CP}$ & 11.28 & 15.49 & 12.00 & 11.92 & 11.68 \\
\hline TDN* & 40.88 & 38.38 & 60.00 & 59.80 & 59.39 \\
\hline
\end{tabular}

Source: Proximate Analysis Results at the Animal Feed and Nutrition, Faculty of Animal and Agricultural Sciences, Diponegoro University, Semarang (2017)

*Calculation Results according to Sutardi (2001).

4. Equation for VFA:

VFA Prod $(m M)=(a-b) \times N ~ H C l ~ \times 1000 / 5 \ldots . .(4)$

$\mathrm{a}=$ Blanks Titran Volume $(\mathrm{ml})$

$\mathrm{b}=$ Sample Titran Volume (ml)

\section{Data Analysis}

Data generated from in vitro test were analyzed using Costat program for variance analysis (ANOVA) at 95\% significance level followed by a Duncan Multiple Range Test (DMRT) test if there were differences between treatments.

\section{Results and Discussion}

Diversity of nutrient value from different feedstuffs requires easier and more efficient nutrient evaluation method (Khanum et al., 2007). Ration fed to sheep should be specially composed and formulated. The nutrient content of ration can be determined from its chemical ration, while nutrient intake can be determined biologically from digestibility test and fermentation rate by means of in vitro method (Khanum et al., 2007). Tilley and Terry's in vitro method is the commonly method used to evaluate feed's nutrient intake of ruminant and proven to be more accurate to predict digestibility (Mabjeesh et al., 2000). This method has two stages i.e. digested using rument liquid buffer for 48 hours and digested by using pepsinHCL liquid for 48 hours (Tilley and Terry, 1963).

Feed intake is an important indicator to predict feed's nutrient intake that can be digested by digestive system. Low digestibility indicator that the feedstuffs have less ability to supply nutrient for production and reproduction needs (Mayulu, 2014). In vitro analysis can determine dry matter digestibility (DMD), organic matter digestibility (OMD), $\mathrm{NH}_{3}$ fermentation level, and volatile fatty acid (VFA) fermentation level (Tilley and Terry, 1963). Average of in vitro analysis of sheep's local feed ration is shown in Table 2.

\section{Dry Matter and Organic Matter Digestibility}

Digestibility is an initial indication of various nutrients availability contained in a feedstuffs to be consumed by the livestock. Large amount of digested nutrient intake shows that feed has high digestibility. Feed that has low digestibility shows 
that thus feed has less supply of nutrient to livestock (Mayulu, 2012).

Table 2. Average ofin vitro $\mathrm{DMD}, \mathrm{OMD}, \mathrm{NH}_{3}$ and VFA analysis of sheep fed with local feed ration

\begin{tabular}{ccccc}
\hline Treatment & $\begin{array}{c}\text { DMD } \\
(\%)\end{array}$ & $\begin{array}{c}\text { OMD } \\
(\%)\end{array}$ & $\begin{array}{c}\mathrm{NH}_{3} \\
(\mathrm{mM})\end{array}$ & $\begin{array}{c}\text { VFA } \\
(\mathrm{mM})\end{array}$ \\
\hline $\mathrm{T}_{1}$ & $41.93^{\mathrm{b}}$ & $52.72^{\mathrm{b}}$ & $4.61^{\mathrm{c}}$ & $47.75^{\mathrm{ab}}$ \\
$\mathrm{T}_{2}$ & $42.71^{\mathrm{b}}$ & $49.13^{\mathrm{b}}$ & $4.14^{\mathrm{c}}$ & $24.50^{\mathrm{c}}$ \\
$\mathrm{T}_{3}$ & $55.86^{\mathrm{a}}$ & $60.86^{\mathrm{a}}$ & $6.07^{\mathrm{a}}$ & $41.50^{\mathrm{b}}$ \\
$\mathrm{T}_{4}$ & $56.41^{\mathrm{a}}$ & $61.87^{\mathrm{a}}$ & $4.79^{\mathrm{bc}}$ & $44.00^{\mathrm{ab}}$ \\
$\mathrm{T}_{5}$ & $56.51^{\mathrm{a}}$ & $62.48^{\mathrm{a}}$ & $5.85^{\mathrm{ab}}$ & $55.25^{\mathrm{a}}$ \\
\hline
\end{tabular}

Remarks: Different superscribs show significant different $(P<0.05)$

$\mathrm{T}_{1}=100 \%$ of Leersia hexandra

$\mathrm{T}_{2}=100 \%$ of Neptunia plena

$\mathrm{T}_{3}=$ Ration $(15 \%$ Neptunia plena+ $15 \%$ Leersia hexandra+ $70 \%$ other feedstuffs)

$\mathrm{T}_{4}=$ Ration (20\% Neptunia plena+ $20 \%$ Leersia hexandra+ $60 \%$ other feedstuffs)

$\mathrm{T}_{5}=$ Ration $(25 \%$ Neptunia plena+ $25 \%$ Leersia hexandra+ $50 \%$ other feedstuffs)

Analysis of variance result on in vitro DMD analysis of sheep's local feed ration (Table 2) showed that the score of DM digestibility from highest to lowest were $T_{5}, T_{4}, T_{3}$, and followed by $T_{2}, T_{1}$. Average of $D M$ digestibility from those five treatments showed significant difference $(P<0.05)$. DMRT test result of averageDMD showed that $T_{5}$ was significantly different to $T_{2}$ and $T_{1}$ but not significantly different to $T_{4}$ and $T_{3}$, average DMD of $T_{2}$ wasn't significantly different to $T_{1}$. Analysis result showed that in vitro DMD analysis was influenced by sheep's local feed ration.

The result of this research showed that utilization of local feed as ration with CP $11.68 \%$ and TDN $59.39 \%$ on the five treatments showed that DM digestibility (56.51\%) was better than consumption of single local feed in $\mathrm{T}_{1}(100 \%$ of Leersia hexandra) $(41.93 \%)$ and $T_{2}(100 \%$ of Neptunia plena) (42.71\%) (Table 2). Thus was caused by digestibility was influenced by several factors including the physical shape of feedstuffs, ration composition, comparison composition amongst the feedstuffs material, feed treatment, enzyme supplementation inside the feed, livestock and feed provision level (Sandi et al., 2015; Priyanto et al., 2017). Research resulted by Trisnadewi et al., (2014) on in vitro DM digestibility of gamal substitution (Gliricidia sepium) with calliandra (Calliandra calothyrsus) on ration resulted the highest DM digestibility was $38.85 \%$. Thus result was still lower from this research's result i.e. $56.51 \%$.

A decreasing DM digestibility is clearly associated with the increasing fraction of Neutral Detergent Fiber (NDF) and Acid Detergent Fiber (ADF) and increasing of lignification process and decreasing comparison between leaves and stem. Changing in leaves and stem ratio will change the leaves chemical composition, leaves contain of easier digested-feed composition compared with stem. Stem is a part of plant which support the plant structure thus has higher lignin content (Bonneau and Laarveld, 1999).

Feed intake depends on rument microorganism activities as they contribute in fermentation process, while rumen microorganism activities are influenced by food susbtances contained inside the feedstuffs (Sandi et al., 2015). Number and activity microorganisms reflects increased digestibility (Mayulu, 2014). Ration's feedstuffs which contain of high crude fiber, thicker and more compact cell wall cause lower feed intake. Meanwhile, feedstuffs having lower crude fiber generally has higher feed intake because the cell wall is thin thus can be penetrated by digestive latex (Riswandi et al., 2015). Rumen microorganism can synthesize and secresize cellulose enzyme $\beta$ 1-4 which roles on hydrolyzing plant cell wall thus high crude fiber feedstuffs can be degraded into high quality feedstuffs (Lunagariya et al., 2017). Microorganism of synthesis up to $30-40 \mathrm{~g} / \mathrm{kg}$ of digestible organic matter or equal to $187.5-250 \mathrm{~g}$ protein of microorganism $/ \mathrm{kg}$ of digestible organic matter (Mayulu, 2014). 
Analysis of variance result on in vitro OMD of sheep's local feed ration is shown in Table 2. It showed average of OM digestibility from the largest to lowest was $T_{5}, T_{4}, T_{3}$, and followed by $T_{2}$, $T_{1}$. The score showed that the five treatments were significantly different $(P<0.05)$. Duncan Multiple Range Test result test of OM digestibility showed that $T_{5}$ was significantly different to $T_{2}$ and $T_{1}$, but not significantly different to $T_{4}$ and $T_{3}$; and $T_{2}$ was not significantly different to $T_{1}$. Analysis result showed that in vitro OM digestibility score was significantly influenced by sheep's local feed ration.

The result of this research proved that the utilization of local feed as ration with CP $11.68 \%$ and TDN $59.39 \%$ in $T_{5}$ showed that OM digestibility was better (62.48\%) compared with single feedstuffs material in $\mathrm{T}_{1}$ with $100 \%$ Leersia hexandra (52.72\%) and $\mathrm{T}_{2}$ with $100 \%$ Neptunia plena (49.13\%). Organic matter digestibility is closely associated with DMD because part of DM is OM which contains of $\mathrm{CP}, \mathrm{CF}, \mathrm{CF}$ and BETN. Result of Trisnadewi et al. (2014) on gamal substitution (Gliricidia sepium) with calliandra (Calliandra calothyrsus) in ration to in vitro digestibility produced the highest OM was $41.21 \%$. That result was lower than this research's result (62.48\%).

\section{Fermentation Level of $\mathrm{NH}_{3}$ and VFA}

Analysis result of in vitro $\mathrm{NH}_{3}$ fermentation level of sheep's local feed ration (Table 2) showed the highest $\mathrm{NH}_{3}$ fermentation level was found in $T_{3}$ and followed by $T_{5}, T_{4}, T_{1}$, and $T_{2}$. Average of $\mathrm{NH}_{3}$ fermentation level on five treatments showed significantly different $(P<0.05)$. Duncan Multiple Range Test result on average of $\mathrm{NH}_{3}$ fermentation concentration showed that $T_{3}$ was not significantly different to $T_{5}$ and $T_{4}$ but significantly different to $T_{1}$ and $T_{2}$. Analysis result proved that in vitro $\mathrm{NH}_{3}$ fermentation level was influenced by sheep's local feed ration.

The result of this research proved that sheep ration with CP $12.00 \%$ and TDN $60 \%$ in $\mathrm{T}_{3}$ showed that $\mathrm{NH}_{3}$ fermentation level was $6.07 \mathrm{mM}$. Concentration of $\mathrm{NH}_{3} 6,07 \mathrm{mN}$ might be caused by high $\mathrm{CP}$ content in ration $(12.00 \%)$ and nitrogen non protein (NPN) supply in ration as well as high number of microbe contained inside the rumen that used as buffer. Aderinboye et al. (2016) stated that inoculum source (rumen liquid) influenced the $\mathrm{NH}_{3}$ production. This value showed that $T_{3}$ ration can support the microbe growth in rumen because the optimum $\mathrm{NH}_{3}$ ranging between 3.57-7.14 mM. Low concentration of $\mathrm{NH}_{3}$ can be caused by low content of protein or protein resistant to degradation which results in inhibition of carbohydrate degradation. Concentration of $\mathrm{NH}_{3}$ can be a good reference in determining soluble protein supplementation. $\mathrm{NH}_{3}$ synthesis rate inside the rumen highly depends on chemical structure of protein of the ration (Cristiyanto, 2011). High crude protein content in ration is highly required by microbe as nitrogen source for microbe to build up their body protein (Aderinboye et al., 2016).

Ammonia is a product of fermentation activity in the rumen from protein degradation derived from feed and is the main source of nitrogen (N) for bacteria because most (82\%) of bacteria utilizes $\mathrm{NH}_{3}$ as a source of $\mathrm{N}$. Feed nitrogen $40-$ $60 \%$ will be changed into $\mathrm{NH}_{3}$ by rumen microbe and $50-70 \% \mathrm{NH}_{3}$ will be utilized for rumen microbe protein synthesis. Different $\mathrm{NH}_{3}$ production can be caused by different crude protein content among treatments. Feed protein in the rumen will be hydrolyzed by proteolytic enzymes rumen microbes to produce oligopeptides which then undergo further digestion into peptides, some pass rumen degradation and some are hydrolyzed into amino acids (Trisnadewi et al., 2014; Sandi et al., 2015).

Concentration of $\mathrm{NH}_{3}$ in the rumen is a very important quantity to control, because it determines the optimization of rumen microbial growth. High $\mathrm{NH}_{3}$ concentration is determined by the level of feed protein consumed, degree of degradability, length of feed in the rumen, and 
rumen $\mathrm{pH}$. Level of $\mathrm{NH}_{3}$ needed to support maximum rumen microbial biosynthesis is 3.57$7.14 \mathrm{mM}$ (Sunarso, 2003). The growth of microganism in the rumen requires an adequate supply of $\mathrm{NH}_{3}$ derived from feed protein and NPN supplementation in the ration (Riswandi et al., 2017). Rumen microorganism cannot be reproduced if the supply of $\mathrm{N}$ in the rumen is limited (Arora, 1995).

The microbial protein precursors are $\mathrm{NH}_{3}$ and carbon source compound, the increasing $\mathrm{NH}_{3}$ content in the rumen, the more likely microbial protein are formed and role as the protein source for the body. This condition is a reflection of the contribution of $\mathrm{NH}_{3}$ to ruminant (Indriani et al., 2013). The energy available after fiber degradation process and rumen $\mathrm{pH}$ whichis suitable for proteolytic microbial activity affects the concentration of $\mathrm{NH}_{3}$ (Usman, 2013). Availability of $\mathrm{NH}_{3}$ is the most important determinant of microbial protein production because the majority of rumen bacteria use $\mathrm{NH}_{3}$ as a nitrogen source, so it is important to determine $\mathrm{NH}_{3}$ concentration that supports microbial growth by utilizing NPN (Phesatcha and Wanapat, 2016).

The result of ANOVA on in vitro VFA fermentation level in sheep's local feed ration (Table 2), showed the highest average value of VFA fermentation level, namely at $T_{5}$ and sequentially followed by treatment $T_{1}, T_{4}, T_{3}$, and $T_{2}$. The average fermentation rate of VFA on the five treatments showed very significant differences ( $P<0.05)$. The DMRT test result on the average fermentation rate of VFA indicated that $T_{5}$ was not significantly different with $T_{1}, T_{3}$ and $T_{4}$ but significantly different with $T_{2}$. The result of the analysis proved that in vitro VFA fermentation level was influenced by sheep's local feed ration.

The result showed that sheep ration with $\mathrm{CP}$ $11.68 \%$ and TDN $59.39 \%$ in the $T_{5}$ showed a value of VFA fermentation level of $55.25 \mathrm{mM}$. This result was still lower than the VFA value for optimum microbial growth ranging from 80-160
$\mathrm{mM}$ and the value was influenced by the type of feed given. Volatyle fatty acid concentration is influenced by basal feed, type of carbohydrate feed, physical form of feed, consumption level, frequency of feed, and use of chemical additives. Higher VFA concentration indicates an increasing of rumen microbial activity because more organic material is fermented in the rumen (Madrid et al., 2002).

Food substances in the form of carbohydrate and protein strongly support the continuity of metabolic activity in the digestive tract of ruminant. Available carbohydrate is needed by microbes for carbohydrate fermentation and VFA production. The high level of VFA production is an indication that the organic material contained in the ration is very easily degraded by rumen bacteria. Volatile Fatty Acid is formed from the hydrolysis of carbohydrate polysaccharide converted into monosaccharide, especially glucose, then transformed into acetate $\left(C_{2}\right)$, propionate $\left(C_{3}\right)$, butyrate $\left(C_{4}\right)$, isobutane, valerate, isovalerate, methan $\left(\mathrm{CH}_{4}\right)$ and $\mathrm{CO}_{2}$. Acetate is the main acid formed in the rumen from the degradation of sugar by microbes and is the main energy source, the higher the VFA concentration indicates the fermentation process is more effective, however the concentration of VFA that is too high can cause disruption of rumen system balance (Sandi et al., 2015). In general, comparison of VFA in the rumen ranges from $65 \%$ acetate, $20 \%$ propionate, $10 \%$ butyrate, $5 \%$ valerate (Rahmadi et al., 2010). The formation of VFA in the rumen is very important because $70-85 \%$ of ruminant energy comes from VFA (Trisnadewi et al., 2014). The sheep's rumen fluid contains of $53-66 \%$ acetate, $19-27 \%$ propionate, and $12-17 \%$ butyrate (Arora, 1995).

Volatile Fatty Acid fermentation in the rumen is influenced by the type of food consumed. Chemical composition, the physical form of feed consumed affect the retention and digestibility of digesta of the rumen and reticulum. Fibrous feeds that have low digestibility will experience 
gradual degradation because the first physical contact is slow. This condition results in delayed enzyme work and retention in the rumen, so that only small particles can pass the rumen (Usman, 2013).

Site specific local feed resources (Leersia hexandra and Neptunia plena) need to be utilized, and started to be given to livestocks. Should be carried out by farmers in order to obtain nutrient diversity to meet the needs of sheep and/or ruminants in general. The government is obliged to carry out a socialization of the utilization of site specific local feed resources, so that farmers are able to increase their farming productivity through the use of economic feedstuffs.

\section{Conclusions}

Based on the assessment of variance analysis, digestibility value and fermentation level evalution on sheep's local feed ration under in-vitro method can be concluded as follows:

1. Dry matter digestibility of local feed-based ration had a very significant effect on treatments $T_{5}, T_{4}$, dan $T_{3}$ respectively at 56.51\%; $56.41 \%$; and $55.86 \%$;

2. Organic matter digestibility of local feedbased sheep ration had a very significant effect on treatments $T_{5}, T_{4}$, and $T_{3}$ respectively at $62.48 \% ; 61.87 \%$; and $60.86 \%$;

3. Fermentation of $\mathrm{NH}_{3}$ level of local feedbased ration had a significant effect, the highest concentration occurred in $T_{3}$ treatment i.e. $6.07 \mathrm{mM}$; and

4. Volatyle fatty acid (VFA) fermentation level of local feed-based ration had a significant effect, the highest concentration occurred in $\mathrm{T}_{5}$ treatment i.e. $55.25 \mathrm{mM}$.

\section{Acknowledgment}

The author would like to say thank you to head and staffs Laboratory of Animal Feed and Nutrition, Faculty of Animal and Agricultural Sciences, Diponegoro University, for the supports during the research.

\section{References}

Aderinboye, R.Y., A.O Akinlolu, M. A. Adeleke, G.O. Najeem, V.O.A. Ojo, O. A. Isah, O. J. Babayemi. 2016. In vitro gas production and dry matter degradation of four browse leaves using cattle, sheep and goat inocula. Slovak J. Anim. Sci 49 (1): 32-43.

Adiwimarta. K. I. S. 2012. Pengukuran Kualitas Pakan Sapi (Cattle Feed Quality Measurement). PT. Citra Aji Parama. Jakarta.

Arora, S.P. 1995. Pencernaan Mikroba Pada Ruminansia (Microbial Digestion in Ruminants). Gadjah Mada University Press. Cetakan kedua (Second Edition). Yogyakarta.

Bonneau, M., B. Laarveld. 1999. Biotechnology in animal nutrition, physiology and health. Livestock Production Science 59: 223-241.

Christiyanto, M. 2011. Evaluasi Nutrisi Ransum Berpakan Basal Rumput Raja Dengan Ketersediaan Prekursor Nitrogen-Energi Pada Kecernaan Dan Konsumsi Sapi Peranakan Friesian Holstein (Nutrient Evaluation of King Grass Basal Feed Ration with Availability of Nitrogen-Energy Precursor in Digestion and Consumption of Friesian Holstein Breeds).Dissertation.Gadjah Mada University. Yogyakarta.

Indriani, N., T. R. Sutardi and Suparwi. 2013. Fermentasi limbah soun dengan menggunakan Aspergillus niger ditinjau dari kadar volatyle fatty acid (VFA) total dan amonia $\left(\mathrm{NH}_{3}\right)$ secara in vitro (Fermentation of Cassava Flour Noodle Waste Using Aspergillus niger: A Review on Volatile Fatty Acid (VFA) and Ammonia ( $\mathrm{NH}_{3}$ ) by In Vitro). Jurnal Ilmiah Peternakan 1 (3): 804-812 (J. of Animal Science).

Kementerian Pertanian (Ministry of Agriculture). 2017. Sub Sektor Peternakan untuk populasi domba (Livestock Sub Sector for Sheep Population). [Downloaded on 01 December 2017]. Available at: http://pertanian. go.id/ap_pages/mod/datanak.

Khanum, S.A., T. Yaqoob, S. Sadaf, M. Hussain, M. A. Jabbar, H. N. Hussain, R. Kausar, and S. Rehman. 2007. nutritional evaluation of various feedstuffs for livestock production using in vitro gas method. Pakistan Vet. J 27 (3): 129-133.

Lunagariya. P. M., R. M. Gupta, dan S. Parnerkar. 2017. in vitro evaluation of total mixed ration supplemented with exogenous fibrolytic enzymes for crossbred cows. Veterinary World 2231-0916: 281-285.

Madrid, J., M. D. Megias, dan F. Henandeminaz. 2002. In vitro determination of ruminal dry matter and cell wall degradation, and production of fermentation end-product of various by- products. Anim. Res.51: 189-199. 
Mabjeesh. S. J., M. Cohen, dan A. Arieli. 2000. In vitro methods for measuring the dry metter digestibility of ruminant feedstuffs: comparison of methods and inoculum source. Journal of dairy science 83 (10): 2289-2294.

Mansjoer, S. S., T. Kertanugraha, and T. Sumantri. 2007. Estimasi jarak genetik antar Domba Garut tipe tangkas dengan tipe pedaging (Estimation of genetic distance between fighting and meat types of Garut sheep). Media Peternakan (J. of Animal Science and Technology) 30. 129-138.

Mayulu, H. 2012. Optimasi Sumberdaya Pakan Ruminansia Berbasis Agroekosistem Perkebunan Kelapa Sawit Melalui Teknologi Complete Feed(Optimization of Ruminant Feed Resources Based on Oil Palm Plantation Agroecosystems through Complete Feed Technology). Dissertation. Diponegoro University.Semarang.

Mayulu, H. 2014. The nutrient digestibility of locally sheep fed with amofer palm oil byproduct-based complete feed. Internat. J. Sci. Eng 7 (2): 106-111.

Phesatcha. K dan M. Wanapat. 2016. Improvement of nutritive value and in vitro ruminal fermentation of Leucaena silage by molasses and urea supplementation. Asian Australas. J. Anim. Sci 29 (8): 1136-1144.

Priyanto, A., A. Endraswati, Rizkiyanshah, N. C. Febriyani, T. Nopiansyah and L.K Nuswantara. 2017. Pengaruh pemberian minyak jagung dan suplementasi urea pada ransum terhadap profil cairan rumen $\left(\mathrm{KcBK}, \mathrm{KcBO}, \mathrm{pH}, \mathrm{N}-\mathrm{NH}_{3}\right.$ dan total mikroba rumen) (Effect of corn oil and urea supplementation in ration on rumen fluid profile (DMD, OMD, $\mathrm{pH}, \mathrm{N}-\mathrm{NH} 3$ and total rumen microbes). Jurnal Imu Ternak (J. of Animal Science) 17 (1): 1-9.

Rahmadi, D., Sunarso, J. Achmadi, E. Pangestu, A. Muktiani, M. Christiyanto, Surono, and Surahmanto. 2010. Ruminologi Dasar (Basic Ruminology). Diponegoro University. Semarang.

Riswandi, Muhakka and M. Lehan. 2015. Evaluasi nilai kecernaan secara in vitro ransum ternak Sapi Bali yang disuplementasi dengan probiotik bioplus (Evaluation of in vitro digestibility of Bali cattle ration supplemented with bioplus probiotics). J. of Sriwijaya Animal Science4 (1): 35-46.

Riswandi, L. Priyanto, A. Imsya, Meilia, and Nopiyanti. 2017. Kecernaan in vitro ransum berbasis rumput Kumpai (Hymenachne acutigluma) fermentasi disuplementasi legume berbeda (In vitro digestion of fermented Kumpai (Hymenachne acutigluma) grass-based ration supplemented with different legume). Jurnal Peternakan Sriwijaya (J. of Veterinary) 18 (2): 303-311.

Sandi, S., A. I. M. Ali and A. A. Akbar. 2015. Uji in vitro wafer ransum komplit dengan bahan perekat yang berbeda (In vitro test of complete wafer ration with different adhesives). Jurnal Peternakan Sriwijaya (J. of Sriwijaya Animal Science). 4 (2) pp. 7-16.

Sunarso. 2003. Pakan ruminansia dalam sistem integrasi ternak-pertanian (Pidato Pengukuhan Guru Besar Universitas Diponegoro 10 September 2003) (Ruminants Feed in the livestock-farming integration system (Speech for Professor Inauguration of Diponegoro University 10 September 2003). Diponegoro University Publishing Board Semarang, Semarang.

Sutardi, T. 2001. Revitalisasi peternakan sapi perah melalui penggunaan ransum berbasis limbah perkebunan dan suplemen mineral organik (Revitalizing dairy farming through the use of plantation waste-based ration and organic mineral supplements). RUT Research VIII.1. Ministry of Research and Technology with the Indonesian Institute of Sciences. Bogor.

Tilley, J. M. A. and R. A. Terry. 1963. A two stage technique for the in vitro digestion of forage crop. Journal of the British Grassland Society 18: 104111.

Trisnadewi, A.A.A.S., I.G.L.O. Cakra, I. W. Wirawan, I.M. Mudita, and N. L. G. Sumardani.2014. Substitusi gamal (Gliricidia sepium) dengan kaliandra (Calliandra calothyrsus) pada ransum terhadap kecernaan in-vitro (In vitro digestion of Gamal (Gliricidia sepium) substitution with calliandra (Calliandra calothyrsus)-based ration). Pastura: J. of Tropical Forage Science 3 (2): 106109.

Usman. 2013. Pemberian pakan serat sisa tanaman pertanian (jerami kacang tanah, jerami jagung, pucuk tebu) terhadap evolusi $\mathrm{pH}, \mathrm{N}-\mathrm{NH}_{3}$ dan VFA di dalam rumen sapi (Provision of feed from agricultural residual fibers (peanut straw, corn straw, sugar cane shoots) for the evolution of $\mathrm{pH}$, $\mathrm{N}-\mathrm{NH}_{3}$ and VFA in the cattle rumen). Agripet (13) 2: 53-58.

Wiyatna. M. F., E. Gurnadi, and K. Mudikdjo. 2012. Produktivitas Sapi Peranakan Ongole pada Peternakan Rakyat di Kabupaten Sumedang (Productivity of Ongole Breeders in Small Scale Livestock in Sumedang Regency).Jurnal IImu Ternak (J. of Animal Science) 12 (2).

Yakin. E.A., N. Ngadiyono, and R. Utomo. 2012. Pengaruh Substitusi Silase Isi Rumen Sapi pada Pakan Basal Rumput dan Konsentrat terhadap Kinerja Sapi Potong (Effect of Silage Substitution Fill in Cattle Rumen on Basal Grass Feed and Concentrate on Beef Cattle Performance). Buletin Peternakan (AnimalScience Bulletin)36 (3): 174180. 